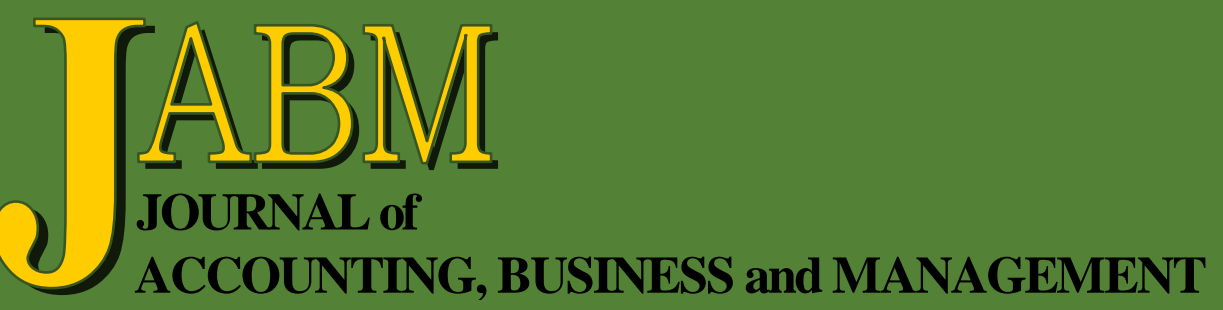

An Analysis of Management Accounting System Development from the Structuration Theory Viewpoint

Anthony Moung Yin Chan, Paul Lo and Kong Ng

Impact of Total Asset Turnover Ratios on Equity Returns: Dynamic Panel Data Analyses

Jeanne-Claire Patin, Matiur Rahman and Muhammad Mustafa

The Impact of Audit Committees on US Nonprofit Organizations'

Governance

Husam Abu-Khadra

Implicit Taxes Amid Race to the Bottom in a Global Tax Game

Igor Semenenko, Junwook Yoo and Parporn Akathaporn

The Adoption of Financial Accounting Standards for Small Medium Enterprises by Muslim Entrepreneurs

Muslichah, Sunarto, Anang Amir Kusnanto, Sri Indrawati and Hariyanto

The Impact of E-Procurement Systems in the Biomedical Industry

A. Seetharaman, Nitin Patwa, Simon Lai Koek Wai and Ahammed Shamir

After-Tax Discounting: A Research Edge

Hongtao Guo

Rules-Based Accounting Standards and SEC Enforcement

Devon Baranek 
Journal of Accounting, Business and Management vol. 27 no. 1 (2020) 54-65

\title{
The Adoption of Financial Accounting Standards for Small Medium Enterprises by Muslim Entrepreneurs
}

\author{
Muslichah* \\ Sunarto ${ }^{\dagger}$ \\ Anang Amir Kusnanto $\ddagger$ \\ Sri Indrawati \& \\ Hariyanto $^{* *}$
}

\begin{abstract}
This study aims to discuss the adoption of financial reporting and accounting standards for small-medium enterprises (SMEs) by Muslim entrepreneurs. A structured questionnaire was used to collect quantitative data from the SME owners. 214 Muslim owners of SME businesses participated in the survey. The results show that only a few Muslim entrepreneurs prepared financial reports regularly. The main reason for preparing the statement is for calculating tax, borrowing money, and decision making. An unexpected finding from this study is that most of the Muslim owners are unaware of Standard for SMEs. Users of SME financial reports include tax authority, banks, and owners, or shareholders. This study enriches the financial reporting studies by examining the accounting standards for SMEs in a Muslim dominated country. The findings of this study also have implications for the Institute of Indonesia chartered accountants (IICA) as standard setter. IICA must routinely disseminate these standards to SMEs and also assist them in preparing financial reports.
\end{abstract}

Keywords: financial reporting, standard, muslim entrepreneurs, SME.

\section{INTRODUCTION}

The SME sector has a vital role in driving the growth of the economy. With the existence of the sector, unemployment, which is not absorbed in the world of work, is reduced. Small Medium Entreprises (SMEs) have a strategic role in combating poverty and unemployment. SMEs contribute towards job creation, economic development, and poverty alleviation across the world (Reddy, 2007; Lind, 2012; and Sava et al., 2013). SMEs have a significant and strategic role in Indonesia's economic development. In addition to playing a role in economic growth and employment, SMEs also play a role in distributing development results. The contribution of the micro, small, and medium business sector to the gross domestic product in 2018 will be $60.34 \%$. Labor

\footnotetext{
* Professor of Accounting. STIE Malangkuçeçwara. Jl. Terusan Candi Kalasan, Malang, Indonesia. Phone: +62-341-491813. E-mail: muslichahmachali21@gmail.com or muslich@ stie-mce.ac.id.

†Lecturer of Accounting. STIE Malangkuçeçwara. Jl. Terusan Candi Kalasan, Malang, Indonesia. Phone: +62-813-3386-8416. E-mail: dmsunarto@gmail.com.

‡Lecturer of Management. STIE Malangkuçeçwara. Jl. Terusan Candi Kalasan, Malang, Indonesia. Phone: +62-813-3480-5399. E-mail: Amirkurnanto@gmail.com.

$\checkmark$ Lecturer of Management. STIE Malangkuçeçwara. Jl. Terusan Candi Kalasan, Malang, Indonesia. Phone: +62-813-3503-5263. E-mail: Sriindrawati48@gmail.com.

** Lecturer of Management. STIE Malangkuçeçwara. Jl. Terusan Candi Kalasan, Malang, Indonesia. Phone: +62-813-3322-7883. E-mail: hariyanto27656@yahoo.com.
} 
absorption in the sector was $97.22 \%$ in the same year. SMEs have succeeded in absorbing around 121 million workers.

For SMEs to continue to grow and contribute to the Indonesian economy, SME owners must continue to monitor their financial condition. One report that is used as a basis for assessing company performance is financial statements. The report is also a source of information that can be used as a basis for decision making. The significance of financial choices is evident from the higher failure rates among small companies (Van Praag, 2003). Financial statements are the main source of information that influences decision making (Carraher \& Van Auken, 2013). The statements consist of vital information that provides the data needed to conduct various kinds of financial analysis, which are important not only for the owner but also for other stakeholders. Financial reports provide useful information for financial decision making, both those related to investment and lending (Akhtar \& Liu, 2018).

To improve the quality of financial reporting, IICA has developed financial accounting standards. Accounting standards are rules and guidelines of accounting principles and practices for various types of business transactions and issues. In January 2018, the IICA released new financial accounting standards for SME. These standards are issued to help SME in Indonesia in preparing financial statements. Financial reports help managers and other stakeholders to evaluate financial information so that they gain a better understanding of many aspects of the business and risk attributes of their firm. However, owners of small firms often do not have the needed expertise to interpret and use their financial statements effectively. Adopting globally accepted financial reporting standards is relevant for small companies because they currently operate in a globalized world (Bunea-Bontus \& Petre, 2010; Adetula \& Owolabi, 2014). Prior research shows that in the SME sector, only a small percentage provide financial reports following accounting standards (Aboagye-Otchere \& Agbeibor, 2012; Hendrian \& Hadiwidjaja, 2016; and Mawutor et al., 2019). The low adoption of standards in SMEs due to the complexity of these standards (Perera \& Chand, 2015).

There have been many studies examining the adoption of standards in SMEs. Only a few previous studies have examined the adoption of standards from a cultural perspective. Accounting is not just numbers and financial reports. It adheres to basic rules and standards to safeguard professional goals but is also shaped by various internal and external forces. The practice of accounting symbolizes the culture in which it is performed. Religion is a cultural obstacle to the adoption of the standard in some countries and some institutions (Akman, 2011; Dowa et al., 2017; and Herath \& Alsulmi, 2017). One element of culture is societal values, which include norms, ethics, belief systems, religion, and philosophy (Haniffa \& Hudaib, 2007). Accounting is a socio-technical activity involving the interaction of both human and non-human resources; therefore, accounting practice cannot be culture-free (Violet, 1983). Religious beliefs are a subset of a culture's total beliefs, and those beliefs may influence accounting performance (Kanagaretnam et al., 2015). More importantly, Findings suggest that religion plays a critical role in shaping individuals' values and entrepreneurial behaviors (Gursoy et al., 2017).

Islamic accounting practice does not indicate to mandate any particular form of reporting. The needs for transparent and useful financial reporting practices to satisfy the needs and accountabilities of the stakeholders require Muslim entrepreneurs to provide financial reporting. In Islam, Muslim entrepreneurs are motivated to provide financial reporting because they are holders of Amanah (trustee of Allah) on earth. Financial reporting functions to discharge the accountability of an enterprise. In 
Muslim societies, the concept of responsibility has been embedded in the creation of basic human beings as the caliph of Allah on earth. Man's mission on earth is to fulfill the purpose of his existence in the universe. Humans are thus created as guardians and are responsible for all their actions. Therefore, all business actors (including Muslim entrepreneurs) must be responsible for what they do both to God and to the society (Baydoun \& Willet, 2000). In Islam, the purpose of preparing financial statements is not only intended to calculate profit and loss, but also accountability to Allah SWT for the use of assets as a mandate. Hameed (2000) suggests that the Islamic Businessman should provide not only financial statements but also additional reports, such as rakat, information regarding the social and environmental impacts of a company. Allazzani (2019) finds that Muslim CEOs are significantly associated with greater disclosure of information. This study aims to explore the adoption of financial statements by Muslim entrepreneurs, whether they have prepared the report based on the SME standards issued by IICA.

\section{LITERATURE REVIEW}

\subsection{Characteristics of Entrepreneurs from an Islamic Perspective}

In Islam's view, there is no separation between business and religion. Islamic entrepreneurship that is in accordance with the Quran and hadiths is entrepreneurship that is able to strike a balance between material and spiritual goals as Muslims (Oukil, 2013; Gursoy et al., 2017). Faizal et al. (2013) explained that the characteristics of entrepreneurs based on al-Qur'an and al-Hadiths are:1) taqwa as a framework, 2) worship to Allah SWT is a priority, 3) halal as a top priority, 3) do not waste, 4) practicing high moral value, 5) trustworthy, 6) concern for the welfare, 7) knowledgeable, and 8) caring for the society and environment. The characteristic is shown in Table 1 below.

\section{Table 1}

Characteristics of Entrepreneurs from an Islamic Perspective

\begin{tabular}{|c|c|}
\hline The Characteristics & Description \\
\hline $\begin{array}{l}\text { Taqwa as the Primary } \\
\text { Basis }\end{array}$ & $\begin{array}{l}\text { Taqwa is the whole attitude consisting of aspects of the faith, the } \\
\text { ritual aspect, and the social aspects. }\end{array}$ \\
\hline Worship to Allah is the & Worship is divided into worship of the heart, oral, and limbs. \\
\hline Priority & $\begin{array}{l}\text { Worship of the heart, for example, tawakal, raghbah (happy), } \\
\text { and rahbah (fear). Whereas tahlil, takbir, tahmid, and verbal } \\
\text { gratitude are oral worship. Prayers, zakat, hajj, and jihad are } \\
\text { bodily worship. }\end{array}$ \\
\hline Halal is a Top Priority & $\begin{array}{l}\text { Using halal materials and transportation and implementing halal } \\
\text { procedures }\end{array}$ \\
\hline Do not Waste & Utilize all resources efficiently and effectively \\
\hline $\begin{array}{l}\text { Practicing High Moral } \\
\text { Value }\end{array}$ & $\begin{array}{l}\text { Not involved in all activities that are prohibited by Islam such as } \\
\text { usury, bribery, fraud, embezzlement, etc. }\end{array}$ \\
\hline Trustworthy & $\begin{array}{l}\text { Carry out the work as well as possible, including honest, trusted, } \\
\text { fulfilling promises, etc. }\end{array}$ \\
\hline $\begin{array}{l}\text { Concern for } \\
\text { the Welfare }\end{array}$ & $\begin{array}{l}\text { Helping people in need, for example through zakat, infaq, and } \\
\text { sadaqah. }\end{array}$ \\
\hline Knowledgeable & $\begin{array}{l}\text { Continuously renewing new knowledge, both worldly and } \\
\text { hereafter, such as company management, financial management, } \\
\text { accounting, etc. }\end{array}$ \\
\hline $\begin{array}{l}\text { Caring for the Society } \\
\text { and Environment }\end{array}$ & $\begin{array}{l}\text { Production does not endanger the safety and health of the } \\
\text { surrounding community and environmental sustainability. }\end{array}$ \\
\hline
\end{tabular}




\subsection{Accounting in Islamic Perspective}

Islam regulates all aspects of life, including issues of livelihood (trade) (Uddin, 2003; Alamad, 2019). Islam requires its people to record when making economic transactions. This command is essential. The order to record is explained in the AlBaqarah verse 282 as follows "O you who believe! When you contract a debt for a fixed period, write it down. Let a scribe write it down in justice between you. Let not the scribe refuse to write, as Allah has taught him, so let him write. Let him (the debtor) who incurs the liability dictate, and he must have Taqwa of Allah, his Lord, and diminish not anything of what he owes".

The recording is essential for several reasons. First, a record can be used as evidence when disputes occur. As mentioned in Al Baqarah 282, "when you contract a debt for a specified term, write it down. Let a scribe write [it] between you injustice". Second, the record that can be used to calculate the zakat obligation as ordered by Allah in the Surah Al-Baqarah 43 and establish prayer and give zakah and bow with those who bow". Third, determine and count the rights of associate friends. The Qur'an has hinted to that which is the word of Allah in verse 24 of As-Shaad "He has certainly wronged you in demanding your ewe [besides] to his ewes. And indeed, many associates oppress one another, except for those who believe and do righteous deeds - and few are they".

\subsection{Accounting Standards for SME}

The main purpose of financial statements is to provide information regarding the financial position, performance, and changes in the financial position of a company that is useful for a wide range of users in making economic decisions. Accountants prepare financial statements to users of financial statements - ranging from company management, tax authorities, to potential investors - need access to financial statements. The report is expected to provide a reliable and useful picture of the organization's finances, made according to the standards developed by the accounting profession. SME Standards determines that The minimum financial statements consist of a statement of financial position (balance sheet), income statement for the period, notes to the financial statements.

\section{Balance Sheet}

A balance sheet is a summary of financial position, which includes assets, debt, and capital at a specific date, for example, the end of the semester, end of the year. The balance sheet, or statement of financial position, presents a portrait of the company's resources (assets) and claims for these resources (liabilities) and shareholders' equity on a specific date. The balance sheet consists of three components, namely, assets, liabilities, and capital.

\section{Income Statement}

The income statement summarizes income and expenses as well as gains and losses. There are several main components in the income statement, including income, expenses, and profit and loss. The profit or loss position can be seen from the comparison of the amount of income obtained with the cost burden incurred by the company. If the company's total income is greater than the total expense, the company is in a profit position. But conversely, if the company's total income is smaller than the overall expense, then the company is at a loss.

\section{Notes to Financial Statement}

This statement contains significant accounting policies, and clarifies other information, for example information about the type of depreciation method used, 
uncollectible accounts, disputes over assets in the process of litigation, reasons for changes of the depreciation method.

\section{METHODOLOGY}

This research conducted using descriptive analysis. In the current study, a questionnaire was used to seek answers from participants to provide an understanding of the research objectives. The respondents of this study were Muslim entrepreneurs whose businesses were categorized as small and medium-sized businesses. The questionnaire consists of two parts, demographic items, and financial reporting questions. Demographic questions included age, gender, educational background, and type of business. Financial reporting questions contains five questions about the adoption of financial reporting and its standard. Research conducted in seven cities di East Java. Data was collected with the help of government staff. Three hundred questionnaires were distributed, 214 returned, yielding a $71.33 \%$ response rate. Small and medium-sized enterprises defined under law no. 20 of 2008. The definition of SME in Indonesia is regulated under the law, SME is a productive entity owned by an individual or individual business unit, excluding foreign-owned or foreign-invested firms. It is defined by both assets (excluding land and buildings) and annual sales, as set out in Table 2.

Table 2

Definition of SME in Indonesia under Law no. 20 of 2008

\begin{tabular}{lllc}
\hline \multirow{2}{*}{ No } & \multicolumn{1}{c}{ Category } & \multicolumn{2}{c}{ Criteria } \\
\cline { 3 - 4 } & & Asset in Rupiah & Sales in Rupiah \\
\hline 1 & Small Enterprises & $>50$ million-500 million & $>300$ million-2.5 billion \\
2 & Medium Enterprises & $>500$ million-10 billion & $>2.5$ billion-50 billion \\
\hline
\end{tabular}

\section{RESULTS AND DISCUSSION}

\subsection{Respondents' Profile}

Table 3

Table 3 below shows the Muslim entrepreneurs involved in this study.

Respondents' Profile

\begin{tabular}{|c|c|c|c|}
\hline \multicolumn{2}{|c|}{ Description } & Frequency & Percentage ( $\%)$ \\
\hline \multirow[t]{4}{*}{ Age: } & $<29$ years & 21 & 9.8 \\
\hline & 30-39years & 69 & 32.2 \\
\hline & 40-49years & 99 & 46.3 \\
\hline & $>50$ years & 25 & 11.7 \\
\hline & Total & 214 & 100 \\
\hline \multirow{2}{*}{ Gender: } & Male & 76 & 35.5 \\
\hline & Female & 138 & 64.5 \\
\hline & Total & 214 & 100 \\
\hline \multirow{3}{*}{$\begin{array}{l}\text { Educational } \\
\text { level: }\end{array}$} & Junior high school & 28 & 13.1 \\
\hline & Senior high school & 126 & 58.9 \\
\hline & Bachelor degree & 60 & 28 \\
\hline & $\overline{\text { Total }}$ & 214 & 100 \\
\hline \multirow{3}{*}{$\begin{array}{l}\text { Type of } \\
\text { business: }\end{array}$} & Service & 35 & 16.4 \\
\hline & Trading & 111 & 51.9 \\
\hline & Manufacturing & 68 & 31.8 \\
\hline & Total & 214 & 100 \\
\hline
\end{tabular}


Based on Table 3, it can be seen that 21 respondents or $9.8 \%$ aged $<29$ years, 69 respondents or 32.2\% aged between 30-39 years, 99 respondents or $46.3 \%$, aged between 36-45 years, and over 45 years as many as 25 respondents or $11.7 \%$. Table 3 also shows that the majority of respondents are female, which is 138 people or $64.5 \%$, while the rest are male, as many as 76 people or $35.5 \%$. Furthermore, respondents have various levels of education, ranging from junior high school to graduate degree. It appears that the majority of respondents (126 or $58.9 \%$ ) have a high school education level. Lastly, respondents have different types of businesses. Table 3 above also shows that 68 respondents owned a manufacturing business. One hundred eleven respondents have a trading business, and the remaining 35 respondents have a service business.

\subsection{Findings and Discussion}

\subsubsection{Adoption of Financial Reporting}

Table 4 below presents the adoption of the financial statement by Muslim entrepreneurs.

\section{Table 4}

\section{Adoption of Financial Statement}

\begin{tabular}{lcc}
\hline & Frequency & Percentage (\%) \\
\hline Yes, routinely prepare & 58 & 28.4 \\
Yes sometimes & 37 & 18.1 \\
Do not prepare & 109 & 53.4 \\
\hline \multicolumn{1}{c}{ Total } & 214 & 100
\end{tabular}

Based on table 4 above, it can be seen that most respondents (109 respondents or $53.4 \%$ ) did not prepare financial reports. Furthermore, as many as 58 or $28.4 \%$ of respondents regularly make financial reports, and the remaining 37 or $18.1 \%$ of respondents sometimes prepare financial statements. Many SME owners do not prepare the financial statements because they assume that the accounting process requires a significant amount of time and costs, is not balanced with the benefits obtained (Maseko \& Manani, 2011; Apak et al., 2012). The findings also indicate that Muslim entrepreneurs are not yet aware of the importance of financial reports as a source of decision making. For SMEs, financial recording and reporting can separate personal assets from business assets, thereby minimizing business risks into personal life, so that Muslim entrepreneurs can run the company more professionally. In relation to decision making, Muslim entrepreneurs can analyze the financial condition of a business to ascertain whether its financial condition is healthy or unhealthy. Thus, they can make decisions regarding asset purchases, employee salary increases, additional loans, etc.

\subsubsection{Reasons for Preparing Financial Statements}

Muslim entrepreneurs, both those who routinely and sometimes prepare financial statements, provide reasons to make the statements, which can be summarized in Table 5 below. Table 5 shows that there are four reasons why Muslim entrepreneurs prepare financial reports; first, as a decision-making tool. Second, to assess the performance of their organization. Third, calculate the tax that must be paid. Fourth, to apply for credit to the Bank.

Insert Table 5 here.

Table 5 shows that $36.8 \%$ t of the entities prepare financial statements for tax purposes, $29 \%$ for a credit application to the banks, $23.2 \%$ for monitoring the company's performance, and $9.6 \%$ for decision making. These findings indicate that the primary external users of the financial statements were the tax authority and banks. 
Existing literature shows that little is known about who users of SME financial statements and what information they need from the report (Son et al., 2006; Sian \& Roberts, 2009; and Dang-Duc, 2011). To date, there are inconsistent findings of users and their information needs from SME financial reports (Son et al., 2006). The primary external users of the financial statements were found to be the tax authority (Collis \& Jarvis, 2000). A slightly different finding is shown by Sian and Roberts (2009), that only the tax authority is the main user of SME financial statements. Table 5 also shows that the primary sources of finance for small enterprises is the bank. The findings of previous studies also indicate that banks are the main source of external finance for SME (Chittenden et al., 1990; Cusmano, 2015), and financial statements play an essential role in their lending decisions (Berry et al., 1987, 1993).

Table 5

Reasons for Preparing Financial Statements

\begin{tabular}{lcc}
\hline & Frequency & Percentage (\%) \\
\hline Tools for decision making & 9 & 9.5 \\
Company performance & 22 & 23.2 \\
Tax purposes & 35 & 36.8 \\
Credit application to the banks & 29 & 30.5 \\
\hline \multicolumn{1}{c}{ Total } & 95 & 100 \\
\hline
\end{tabular}

Furthermore, the lack of using financial statements for decision making indicates that SME owners generally do not have strong skills and have lack an understanding of preparing and interpreting financial statements for critical business decision making (Van Auken et al., 2017). The findings of this study emphasize that financial statements can provide benefits for SMEs, both internally related to performance appraisal and decision making, as well as externally related to banks and taxes. This result is in line with the concept of accounting in Islam is derived from the Qur'an, which makes sample reference to the principles of accounting (Murtuza, 2003). Muslims must record their transactions. The emphasis on recording shows the importance of fulfilling rights and obligations, as stated in the Holy Qur'an. This result suggests that the financial statement has an essential role in enhancing the accountability of their companies. The lack of ability of Muslim entrepreneurs to interpret financial statements indicates their need to increase knowledge related to financial statements. In surah Al-Alaq verses 1-5, Allah SWT commands us to learn by seeking knowledge and distance ourselves from ignorance. Allah says:

"Read (proclaim!) In the name of your Lord who created; Created man, out of a clot (of congealed blood); read (proclaim), and your lord is the most generous; who taught by the pen; taught man that which he knew not" (Al-Alaq, 96: 1-5).

\subsubsection{Types of Financial Statement Presented}

As explained above, there are five types of financial statements. The following Table 6 shows the types of financial statements presented by Muslim entrepreneurs.

Insert Table 6 here.

The most frequently prepared financial statement is income statement (56\%), then Balance Sheet and Income Statement 28\%, then balance sheet, income statement, and notes to a financial statement $(10 \%)$. Muslim entrepreneurs who prepare complete financial reports are still very few (only 2\%). A surprising finding is that Muslim entrepreneurs again rarely compile the Statement of Owners' Equity. This result is 
consistent with Atik (2010), which also finds that the statement of owners' equity is the least frequently prepared statement.

Table 6

Types of Financial Statement Presented

\begin{tabular}{|c|c|c|}
\hline & Frequency & Percentage $(\%)$ \\
\hline IS & 52 & 54.7 \\
\hline BS and IS & 28 & 29.5 \\
\hline BS, IS, NTFS & 10 & 10.5 \\
\hline BS, IS, CFS, SOE & 4 & 4.2 \\
\hline BS, IS, CFS, SOE, NTFS & 1 & 1 \\
\hline Total & 95 & 100 \\
\hline
\end{tabular}

Table 6 above shows that most of the reports presented by Muslim entrepreneurs are balance sheets and income statements. This finding is consistent with the results presented in Table 5 that the primary purpose of preparing financial statements is for tax authorities and loan applications to banks. Compliance refers to the calculation of a firm's tax liability. Taxing authorities want to know whether the company complies with the tax laws. Tax compliance refers to the calculation of a firm's tax liability. Bankers use accounting financial statements to evaluate the risks of lending money. They need information about them so that

funds are loaned only to credit-worthy organizations.

The findings in Table 6 above show that the report presented by Muslim entrepreneurs is a traditional financial report as required by accounting standards. The standards have been greatly affected by secular Western culture, which focuses on the concept of self-interest and ignores welfare for the ummah. As representatives of Allah on earth, Muslim entrepreneurs are responsible not only to God but also to society (Baydoun \& Willet, 2000). Conventional financial statements are not sufficient to fulfill the responsibilities. Additional reports are needed that show the responsibility of Muslim entrepreneurs to the community, for example, reports on zakat, infaq, sadaqah, environment.

\subsubsection{The Reasons for not Preparing Financial Statements}

The following Table 7 shows the reasons why Muslim entrepreneurs did not make financial reports.

Table 7

Reasons for Not Preparing Financial Statements

\begin{tabular}{lcc}
\hline & Frequency & Percentage (\%) \\
\hline Do not know the benefits of FS & 7 & 6.4 \\
Do not have staff/worker & 61 & 56 \\
Wasting time & 6 & 5.5 \\
The government does not oblige & 35 & 32.1 \\
\hline \multicolumn{1}{c}{ Total } & 109 & 100 \\
\hline
\end{tabular}

Note: FS= financial statement.

Table 7 above shows that $56 \%$ of the respondents do not prepare financial statements because they don't have staff/workers. Thirty-five respondents $(32.1 \%)$ because of government does not oblige, 64\% (7 respondents) because of wasting time, and the remaining $5.5 \%$ do not know the benefits of financial statement. Most small enterprises are managed by individuals who concurrently are owners and managers of 
the company, and utilize the workforce from their family and close relatives. Most SMEs are family businesses, and most of the employees are people who are relatives to the business owner (Visser \& Chiloane-Tsoka, 2014).

\subsubsection{Adoption of Accounting Standard}

Table 8 below presents the adoption of a standard by Muslim entrepreneurs.

\section{Table 8}

\section{Adoption of Standard}

\begin{tabular}{ccc}
\hline & Frequency & Percentage (\%) \\
\hline Yes & 3 & 6 \\
No & 47 & 94 \\
\hline Total & 50 & 100
\end{tabular}

An interesting finding from this study is that the majority of Muslim entrepreneurs who prepare financial reports are not aware of the existence of financial reporting standards for SMEs. This result is consistent with the findings of Hendrian and Hadiwidjaja (2016) that only a small percentage of SMEs that have used standard a guide in the preparation of the accounting and financial statements. Similarly, more prominent developed countries that have adopted the full set of IFRS, such as Australia, the United Kingdom, and European Union member states, have not yet adopted IFRS for SMEs. Because of their small size, the cost of compiling financial reporting following standards will burden small businesses (Page, 1984; Keasey \& Short, 1990). In preparing financial statements according to the standards, there must be an improvement in the company's system, because a good system will facilitate the application of standards. Improving the system certainly requires time and money, which can burden Muslim small businesses. Therefore Most of the Muslim entrepreneurs are reluctant to prepare the report.

Furthermore, The prior study revealed that most entities do not know about the IFRS for SMEs (Mawutor et al., 2019). Similarly, Dang-Duc (2011) reveals that SMEs' compliance with accounting standards is limited, and compliance with accounting standards was largely a legal issue, and SMEs perceived little benefits from that. SME Standards compiled by Indonesian accountants' associations have been active since January 1, 2018. However, since the issuance of the standard, intensive socialization has not been carried out to SME owners. It can be understood that many SME owners still do not know and understand these standards. Dowa et al. (2017) found that it is difficult to adopt IFRS in some countries and for some institutions because of the insufficient technical skill and experience of accountants and auditors to deal with those standards. Socialization is intended to provide knowledge and understanding to SME owners about the importance of standards in the preparation of financial statements. But, socialization alone is not sufficient; mentoring is needed so that SME owners can compile financial reports according to standards correctly. Mentoring can be done by involving accountants who work in public accounting firms and lecturers in higher institutions. As stated by Mahmood et al. (2018) that a standard awareness and training program must be carried out routinely by all regulatory and professional bodies so that the actual objectives of the standard-setting can be achieved.

\section{CONCLUSION}

As discussed above, Muslim entrepreneurs should provide financial reporting because they are holders of Amanah (trustee of Allah) on earth. The purpose of preparing financial statements is not only intended to calculate profit and loss, but also accountability to Allah SWT for the use of assets as a mandate. The purpose of this 
study is to discuss the adoption of financial reporting by small and medium scale Muslim entrepreneurs. The results of this study show that not many Muslim entrepreneurs prepare financial statements. The main reason for developing the report is for tax and borrowing money to the bank. The most frequently prepared financial statement is the income statement and balance sheet. As representatives of Allah on earth, Muslim entrepreneurs are responsible not only to God but also to society. Conventional financial statements are not sufficient to fulfill their responsibilities. Additional reports are needed that show the responsibility of Muslim entrepreneurs to society.

An interesting finding of the research is that most of the Muslim owners are unaware of accounting standards for SMEs. Users of SME financial reports include banks and other creditors, the owners, or shareholders. Amanah is a part of faith. Amanah applies to all people, including leaders. The owner of the company is a leader; they will be held accountable for their leadership. This is stated in Surah Al Anfaal verse 27. Accountability is not only to respond to God but includes a responsibility to society, government, and compliance with regulations. Muslim entrepreneurs who act as owners and managers of companies should make financial reports as a part of their accountability.

This study has two primary limitations. First, this study focuses on the perceptions of SME owners; regarding the adoption of financial statements and standards. Subsequent research can examine the readiness of accounting practitioners in the application of standards. Second, the focus of this study was only on small and medium entities in 5 cities in East Java. This study can be extended to another form of company, micro or big companies, and include more cities in East Java. The findings of this study have implications IICA as standard setter and academicians. For existing standards to be adopted by SMEs, IICA, with the help of academicians, should socialize the standards to SMEs and, at the same time, provide mentoring in preparing financial reports for SMEs.

\section{REFERENCES}

Aboagye-Otchere, F., \& Agbeibor, J. (2012, October). The international financial reporting standard for small and medium-sized entities (IFRS for SMEs) suitability for small businesses in Ghana. Journal of Financial Reporting \& Accounting, 10(2), 190-214.

Adetula, D. T., \& Owolabi, F. (2014). International financial reporting standards (IFRS) for SMEs adoption process in Nigeria. European Journal of Accounting Auditing \& Finance Research, 2(4), 33-38.

Akhtar, S., \& Liu, Y. (2018, March/April). SMEs' use of financial statements for decision making: Evidence from Pakistan. The Journal of Applied Business Research, 34(2), 381- 392

Akman, N. H. (2011, July). The effect of IFRS adoption on financial disclosure: Does culture still play a role? American International Journal of Contemporary Research, 1(1), 6-17.

Alamad, S. (2019, May 13). Financial and accounting principles in Islamic finance (1 ${ }^{\text {st }}$ ed.). Switzerland AG: Springer International Publishing.

Apak, S., Erol, M., \& Atmaca, M. (2012). Accounting measures to be taken for the enterprises in difficulty during times of economic crisis: A study on small and medium-sized enterprises (SMEs). African Journal of Business Management, 6(23), 6832-6844. 
Atik, A. (2010). SME's views on the adoption and application of "IFRS for SMEs" in Turkey. European Research Studies, 13(4), 19-31.

Baydoun, N., \& Willett, R. J. (2000). Islamic corporate reports. Abacus: A Journal of Accounting, Finance \& Business Studies, 26(1), 71-90.

Berry, A. J., Faulkner, S., Hughes, M., \& Jarvis, R. (1993, June). Financial information: Banker and the small business. The British Accounting Review, 25(2), 131-150.

Berry, A., Citron, D. \& Jarvis, R. (1987). The information needs of bankers dealing with large and small companies (Research Report 7). London: ACCA.

Bunea-Bontus, C. A., \& Petre, M. C. (2010). The international financial reporting standard for small and medium-sized entities: Pros, cons and challenges. Revista Economica, 6(53), 96-105.

Carraher, S. M., \& Van Auken, H. (2013, May). The use of financial statements for decision making by small firms. Journal of Small Business \& Entrepreneurship, 26(3), 323-336.

Chittenden, F., McConnel, J., \& Risner, C. (1990). The role of the accounting profession in the growth and development of small businesses (ACCA Research Report No. 18). London: CEAT.

Collis, J., \& Jarvis, R. (2000, November 15-17). Financial information: The vital spark in the small enterprise management. Paper presented at the 23 ${ }^{\text {rd }}$ ISBA National Small Firms Policy and Research Conference, Small Firms: Adding the Spark, The Robert Gordon University, Aberdeen.

Cusmano, L. (2015, October 28). New approaches to SME and entrepreneurship financing: Broadening the range of instruments. Pariz: OECD Centre for Entrepreneurship, SMEs \& Local Development.

Dang-Duc, S. (2011, September). Compliance with accounting standards by SMEs in transitional economies: Evidence from Vietnam. Journal of Applied Accounting Research, 12(2), 96-107

Dowa, A., Elgammi, A. M., Elhatab, A., \& Mutat, H. A. (2017, February). Main worldwide cultural obstacles on adopting international financial reporting standards (IFRS). International Journal of Economics \& Finance, 9(2), 172-179.

Faizal, P. R. M., Ridhwan, A. A. M., \& Kalsom, A. W. (2013). The entrepreneurs characteristic from al-Quran and al-Hadis. International Journal of Trade, Economics \& Finance, 4(4), 191-196.

Gursoy, D., Altinay, L., \& Kenebayeva, A. (2017, October). Religiosity and entrepreneurship behaviours. International Journal of Hospitality Management, 67, 8794.

Hameed, S. (2000). The need for Islamic Accounting: Perception of its objectives and characteristics by Malaysia accountants and academics. Unpublished Ph. D. thesis. United Kingdom: University of Dundee.

Haniffa, R., \& Hudaib, M. (2007). Exploring the ethical identity of Islamic banks via communication in annual reports. Journal of Business Ethics, 76(1), 97-116.

Hendrian \& Hadiwidjaja, R. D (2016). Implementation of accounting standard on small and medium-sized entities (SMEs). Global J. Bus. Soc. Sci. Review 4(4), 68-78.

Herath, S. K., \& Alsulmi, F. H. (2017, February). International financial reporting standards (IFRS): The benefits, obstacles, and opportunities for implementation in Saudi Arabia. International Journal of Social Science \& Business, 2(1), 1-18.

Kanagaretnam, K., Lobo, G. , \& Wang, C. (2015, December). Religiosity and earnings management: International evidence from the banking industry. Journal of Business Ethics, 132(2), 277-296. 
Keasey, K., \& Short, H. (1990). The accounting burdens facing small firms: An empirical research note. Accounting \& Business Research, 20(80), 307-313.

Lind, P. (2012). Small business management in cross-cultural environments (pp. 27). New York: Routledge.

Mahmood, Z., Khan, A. B., Ur Rehman, A., \& Atta, S. (2018, June). Preliminary insights on the adoption of international financial reporting standard (IFRS) for small and medium enterprises (SMEs) in Pakistan. Journal of Accounting \& Finance in Emerging Economies, 4(1), 95-110.

Maseko, N., \& Manyani, O. (2011). Accounting practices of SMEs in Zimbabwe: An investigative study of record keeping for performance measurement (a case study of Bindura). Journal of Accounting \& Taxation, 3(8), 171-181.

Mawutor, J. K. M., Williams, S., \& Oduwaa, M. A. (2019). Assessment of the adoption and implementation of IFRS for small and medium scale entities (SMEs). "A study of selected SMEs GA East of Ghana". Asian Journal of Finance \& Accounting, 11(1), 24-258

Murtuza, A., (2003). Islamic antecedents for financial accountability. International Journal of Islam Financial Services 4(1), 73-86.

Oukil, M. S. (2013). Entrepreneurship and entrepreneurs in an Islamic context. Journal of Islamic \& Human Advanced Research, 3(3), 115-130.

Page, M. J. (1984). Corporate financial reporting and the small independent company. Accounting \& Business Research, 14(55), 271-282.

Perera, D., \& Chand, P. (2015, April). Issues in the adoption of international financial reporting standards (IFRS) for small and medium-sized enterprises (SMEs). Advances in Accounting, 31(1), 165-178.

Reddy, M. (2007, March \& June). Small business in small economies: Constraints and opportunities for growth. Social \& Economic Studies, $56(1$ \& 2), 304-321.

Sava, R., Mârza, B., \& Eşanu, N. (2013). Financial reporting for SMEs-past, and perspectives. Procedia Economics \& Finance, 6, 713-718.

Sian, S., \& Roberts, C. (2009, May). UK small owner-managed businesses: Accounting and financial reporting needs. Journal of Small Business \& Enterprise Development, 16(2), 289-305.

Son, D. D., Marriott, N., \& Marriott, P. (2006, September). Users' perceptions and uses of financial reports of small and medium companies (SMCs) in transitional economies: Qualitative evidence from Vietnam. Qualitative Research in Accounting \& Management, 3(3), 218-235.

Uddin, S. J. (2003, January). Understanding the framework of business in Islam in an era of globalization: A review. Business Ethics: A European Review, 12(1), 23-32.

Van Auken, H. E., Ascigil, S., \& Carraher, S. (2017). Turkish SMEs' use of financial statements for decision making. The Journal of Entrepreneurial Finance, 19(1), 1-30.

Van Praag, M. (2003). Business survival and success of young small business owners. Small Business Economics, 21(1), 1-17.

Violet, W. J. (1983). The development of international accounting standards: An anthropological perspective. The International Journal of Accounting, 18(2), 1-12.

Visser, T., \& Chiloane-Tsoka, G. E. (2014, January). An exploration into a family business and SMEs in South Africa. Problems \& Perspectives in Management, 12(4), 427-432. 